\title{
How Is the Debt Managed? Learning from Fiscal Stabilizations
}

\author{
Alessandro Missale, Francesco Giavazzi and Pierpaolo Benigno*
}

September 21, 2000

\begin{abstract}
This paper provides evidence on the behavior of public debt managers during fiscal stabilizations. Such episodes provide valuable information on the way debt instruments are chosen because they allow to overcome the problem that policymakers' expectations of interest rates are generally not observable. We find that governments increase the share of fixed-rate long-term debt denominated in the domestic currency the higher is the conditional volatility of shortterm interest rates, the lower are long-term interest rates, and the stronger is the fall in long-term rates that follows the announcement of the stabilization program. By contrast, conventional measures of the relative cost of issuing long-term debt, such as the long-short interest-rate spread, are not significant. This evidence suggests that debt managers tend to prefer long to short maturity debt because they are concerned about the risk of refinancing at higher than expected interest rates. However, when long-term rates are high relative to their expectations, they issue short maturity debt to minimize borrowing costs.
\end{abstract}

\section{JEL Classification: E63, H63.}

Keywords: credibility, debt maturity, public debt management, stabilization.

Corresponding author: Alessandro Missale; Dip. Studi sullo Stato; Via S. Caterina d'Alessandria 3; 50129 Firenze; Italy. Tel. +39-055-4622920 Fax +39-055-472102. E-mail: missale@unifi.it

*We thank all the people in Treasuries and Central Banks who helped us build a data-base on the composition and maturity of public debt. We are grateful to Pierpaolo Battigalli, Rudi Dornbusch and Prescott Miller for insightful discussions. We also thank Olivier Blanchard, Francesco Daveri, Carlo Favero, Ilan Goldfajn, Mervyn King, Gustavo Piga and Paul Tucker. The paper benefited from the comments of participants to seminars at the Bank of England, MIT, the University of Southampton and the University Warwick. The authors are associated with Università di Firenze and IGIER; Università Bocconi, IGIER, CEPR and NBER; New York University, respectively. 


\section{Introduction}

The positive issue of how policymakers choose debt instruments remains largely unexplored in the literature on debt management. ${ }^{1}$ Although officials often state that minimization of the costs and risks of servicing the public debt are the main goals of debt management, how, in practice, these goals are pursued is not known. ${ }^{2}$ For instance, cost minimization can be attained either creating liquid markets for benchmark bonds and following a predictable issuing strategy, or supplying bonds with characteristics which satisfy investors' demand, or by an active trading strategy based on views about future interest rates. This paper sheds light on this issue by empirically investigating how debt managers behave during a fiscal stabilization.

Fiscal stabilizations provide valuable information on the way debt instruments are chosen because they tend to share a common feature. When a stabilization plan is announced, it typically does not enjoy full credibility among investors: long-term interest rates are thus higher than policymakers' expectations of future rates. This feature of a stabilization thus allows to overcome the problem that policymakers' expectations of future interest rates are generally not observable.

We study 72 episodes of fiscal stabilization occurred in OECD countries between 1975 and 1998. In each case we analyze the government issuing strategy during the first two years of the stabilization. We find evidence that governments, at the start of a stabilization, increase the share of fixed-rate long-term debt denominated in the domestic currency the higher is the conditional volatility of short-term interest rates, the lower are long-term interest rates, and the stronger is the fall in long-term rates that follows the announcement of the stabilization program. By contrast, conventional measures of the relative cost of issuing long-term debt, such as the long-short interestrate spread, are not significant.

This evidence suggests that debt managers tend to prefer long to short maturity debt because they are concerned about the risk of refinancing at higher than expected interest rates. However, when long-term rates are high relative to their expectations, they issue short maturity debt to minimize borrowing costs.

This observation is consistent with the view expressed by Campbell (1995) that a committed government can reduce the cost of debt servicing by issuing short-term debt. High interest rates on long-term bonds may reflect credibility problems, rather than term premia: since the government's resolution to carry out a stabilization is not known to the private sector, long rates may remain high until the time when the uncertainty is resolved. Moreover, issuing short-term debt can yield additional

${ }^{1}$ The possibility of a strategic use of debt characteristics is suggested by Milesi-Ferretti (1995), Uhlig (1997) and Pecchi and Piga (1999). There are few empirical studies of the choice of debt denomination and debt maturity: Calvo, Guidotti and Leiderman (1991), Missale and Blanchard (1994), De Broeck (1997) and Miller (1997a). The normative literature is surveyed in Missale (1997).

${ }^{2}$ See e.g. HM Treasury and Bank of England (2000), Instituto de Gestão do Crédito Público (2000), Ministry of Finance (2000) and Swedish National Debt Office (2000). 
benefits to the extent that it signals the government's intentions: by shortening debt maturity committed governments may distinguish themselves from less determined ones.

We provide a simple formalization of such signaling effects by exploring a reputation game between two governments which differ in their ability to cut spending. Under full information they would both issue long-term bonds to minimize the probability that the stabilization might fail as a result of an exogenous interest rate shock. However, being characterized by different spending cuts, they would face different long-term interest rates. If the government's resolution to cut spending is not known to the public, and spending cuts require time to be implemented, then a lowspending government may face "too high" interest rates on long-term bonds: it may thus want to issue short-term debt to reduce borrowing costs and signal its ability to cut spending. We show that a separating equilibrium exists where the "tough" government shortens debt maturity to signal its determination. The separating maturity is decreasing with the level of the long-term interest rate, and increasing with the variability of interest rates.

The paper is organized as follows. Section 2 presents a simple model of a fiscal stabilization. Section 2.1 describes the choice of debt maturity when the authorities and the private sector share the same information. Section 2.2 introduces asymmetric information and examines separating equilibria. Pooling equilibria are studied in Section 2.3. Section 2.4 summarizes the predictions of the model. The empirical evidence is presented in Section 3. Section 4 concludes.

\section{A simple model of fiscal stabilization}

In this section we present a simple model of fiscal stabilization. The government's objective is to reach a target surplus, $S^{*}$, that can be thought of as the announced budget for the current year within a multi-year stabilization program, or as the surplus needed to stabilize the debt-to-GDP ratio.

The government chooses taxes, $T$, weighting the expected cost of missing the announced target against the costs of distortionary taxation. The expected loss is given by

$$
L=p \Pi+\frac{1}{2} T^{2}
$$

where $p$ denotes the probability that the stabilization fails and $\Pi$ is the fixed cost of failure relative to the cost of taxation.

This loss function has been used by Dornbusch (1991) and Drazen and Masson (1994) in the context of exchange rate stabilization. ${ }^{3}$ The cost of taxation is standard, while the cost of a failed stabilization reflects either the reputational and political

\footnotetext{
${ }^{3}$ More precisely, Drazen and Masson consider the cost of output deviations from target instead of distortionary taxation.
} 
costs of missing the announced budget target, as in Dornbusch (1991), or the higher inflation which may result if the stabilization fails (here described by the fixed term $\Pi$ ), as in Drazen and Masson (1994).

The sequence of events is as follows. In period 0 the government rolls over the public debt deciding the relative amount of one- and two-period bonds to be issued. The current short-term interest rate, $r_{0}$, is known. After the government has decided the composition of the debt, private investors form expectations on the period- 1 interest rate, $r_{1}$ : this determines the interest payments on two-period bonds. When period 1 comes government spending is observed by private investors and all the uncertainty about the period-1 interest rate is resolved. Then, the government rolls over one-period bonds and chooses taxes to meet the announced budget target. However, whether or not the target will be met remains uncertain, since it depends on a shock, $X$, which hits the budget at the end of period 1 .

Setting without any loss of generality $S^{*}$ equal to zero, the probability that the stabilization fails, i.e. the probability of a budget deficit, is equal to

$$
p=\operatorname{Prob}[X>T-G-I]
$$

where $G$ denotes government spending and $I$ the interest payments on the public debt, which depend on the level of interest rates and on the maturity composition of the debt.

To model interest payments it is sufficient to consider $r_{1}$, the interest rate which prevails in period 1 , because the interest rate in period $0, r_{0}$, is known at the time of debt issuance. As we are interested in the relative cost of short- vs. long-term debt, the exact level of $r_{0}$ is irrelevant, and is thus set equal to zero to simplify the notation. Assuming that private investors are risk neutral and denoting with $E_{0}$ the expectation conditional on the information available at period 0 , interest payments are equal to

$$
I=(1-m) r_{1}+m E_{0} r_{1}
$$

where $m$ is the share of two-period bonds issued in period 0 and where the initial level of debt has been normalized to one. (In what follows we shall refer to $m$ as debt maturity.)

$r_{1}$ plays a key role in the choice of debt maturity. Having set $r_{0}$ equal to zero, the cost of two-period bonds is equal to the expectation, at period 0 , of the interest rate, $r_{1}$, which will prevail in period 1, i.e. to the forward rate: $E_{0} r_{1}$. The cost of two-period bonds is thus predetermined. The cost of one-period bonds, instead, is uncertain, since it depends on the interest rate, $r_{1}$, at which such debt will be refinanced in period 1 .

There are two sources of uncertainty affecting $r_{1}$. First, this interest rate is subject to independent exogenous shocks. Second, it depends on government spending, 
and this is not known to the private sector at the time of debt issuance since the government's ability to cut spending is private information. Assuming that government spending only affects the mean of the interest rate, we have

$$
r_{1}=\bar{r}(G)+u
$$

where $\bar{r}(G) \geq 0$ denotes the mean of $r_{1}$ as a function of government spending, and $u$ is an independent shock, distributed on the compact support $\left[u^{l}, u^{h}\right]$, with mean $E_{0} u=0$ and variance $E_{0} u^{2}=\sigma^{2}$.

\subsection{Lengthening debt maturity to minimize refinancing risk}

We first examine the choice of debt maturity, $m$, when the government and the private sector share the same information, that is, when government spending in period 1 , and hence $\bar{r}(G)$, is publicly known. We solve the government problem backward, first deriving the choice of taxes, given debt maturity and interest rates, then the choice of debt maturity.

In period 1 the government minimizes the loss function (1): $p$, the probability of missing the announced budget target, is obtained by assuming that the distribution of the shock $X$ is triangular with mean zero, $E_{1} X=0$, and a support ranging between $-a$ and $a$. (With this assumption we capture the fact that shocks of larger size are less likely to occur). ${ }^{4}$ We consider the right-hand side of the distribution of $X$, since we focus on a government which expects to succeed, in the sense that it chooses a level of taxes, $T^{*}$, for which the expected budget is larger than the announced target, $S^{*}=0$; i.e. it chooses $T^{*}-G-I>0 .^{5}$

Substituting $G+I-T$ in the value of $p$, and replacing $p$ in equation (1), we obtain the loss that the government expects before knowing the realization of $X$, but after observing period 1 interest rates and thus $I$ :

$$
L=\frac{\Pi}{2 a^{2}}(a+G+I-T)^{2}+\frac{1}{2} T^{2}
$$

Then, the optimal value of taxes is equal to $T^{*}=\delta(a+G+I)$ where $\delta=\Pi /\left(a^{2}+\Pi\right)$ is a positive constant.

We now turn to the choice of $m$. Substituting $T^{*}$ in the loss function (5), and taking expectations conditional on the information at time 0 , yields the value of the

\footnotetext{
${ }^{4}$ The result for the optimal share, $m$, holds as a linear approximation for probability density functions decreasing in $X$ over the relevant region.

${ }^{5}$ This government can be thought as being characterized by a high cost of failure, $\Pi$, relative to the level of government spending and the variance of $X$. Formally, the expected surplus is positive if and only if $\Pi>a(G+I)$. It follows that the support of the distribution of $r_{1}$ must also be bounded from above to rule out the possibility that the surplus turns out to be negative because of a large realization of $I$.
} 
loss when the government decides the composition of the debt

$$
E_{0} L^{*}=E_{0} \frac{\delta}{2}[a+G+I]^{2}=E_{0} \frac{\delta}{2}\left[a+G+(1-m) r_{1} B+m E_{0} r_{1}\right]^{2}
$$

which is an increasing and convex function of government spending and interest payments.

The expected loss (6) is minimized choosing $m=1$. By issuing only two-period bonds the government predetermines the amount of interest payments; i.e. it eliminates all uncertainty regarding the cost of debt service. Insulating the budget from interest-rate shocks is optimal because this policy reduces the probability that the stabilization may fail as a result of a negative shock to the interest rate. ${ }^{6}$ Intuitively, a government which expects to succeed will not take bets on interest rates: a negative interest-rate shock increases the probability of failure by a larger amount than a positive shock of the same size reduces it. ${ }^{7}$

The role of long maturities in minimizing the risk that the debt might be refinanced at higher than expected rates is well known to debt managers and emphasized in the literature. In Barro (1995, 1997) long-term debt is optimal since it insulates the government budget from (independently distributed) variations in interest rates and thus allows to smooth tax rates. By reducing roll-over risk, long-term debt may also prevent the emergence of self-fulfilling crises, or speculative attacks, as in Calvo (1988), Alesina, Prati and Tabellini (1990), Giavazzi and Pagano (1990), Obstfeld (1994), Sachs, Tornell and Velasco (1996), among others. In this model a preference for long-term debt also arises quite naturally, but for a different reason: long-term debt is optimal because it increases the probability that the stabilization might succeed.

In this model a government will issue short maturity debt only if the cost of longterm debt is too high relative to its expectations of the interest rate in period 1 . This is the case if investors lack confidence in the government's ability to cut public spending. Credibility problems are considered in the next section.

\footnotetext{
${ }^{6}$ Note that the expected cost of debt servicing at period 0 is independent from the debt composition because of the assumption of risk-neutral investors. With a term premium on two-period bonds, the optimal maturity would be lower than one. However, the analysis would be numerically, though not qualitatively, affected.

${ }^{7}$ This is because the probability of a bad shock, $X>0$, to the budget decreases with the size of the shock. Note that the tax-smoothing motivation implied by the quadratic term $T^{2}$ in the loss function is not sufficient to conclude that long maturity debt is optimal; if $X$ were uniformly distributed, the maturity of the debt would be irrelevant.
} 


\subsection{Shortening debt maturity to signal resolution}

We introduce asymmetric information by assuming that the amount of spending cuts and thus the level of spending in period 1 is not known to private investors. The government can be of two types - tough or weak-depending on the level of spending in period 1. A tough government (carries out larger cuts and) has a level of spending, $G^{L}$, lower than the level of spending, $G^{H}$, of a weak government.

Therefore, from equation (4), the interest rate a tough government faces, $r_{1}^{T}=$ $\bar{r}\left(G^{L}\right)+u$, is expected to be lower than the interest rate faced by a weak government, $r_{1}^{W}=\bar{r}\left(G^{H}\right)+u$. The model thus captures the relationship between government spending and the rate of interest implicit, for example, in a closed economy where agents have finite planning horizons.

Let $s$ be the difference between the expected interest rates faced by the two governments, the informational spread: ${ }^{8}$

$$
s \equiv E_{0} r_{1}^{W}-E_{0} r_{1}^{T}=\bar{r}\left(G^{H}\right)-\bar{r}\left(G^{L}\right)
$$

Except for their mean, the distributions of the two interest rates are assumed to be identical.

As in the previous section, we limit our analysis to the case when both governments are expected to succeed - but the size of the shocks for which they fail differs. Both governments are thus better off the smaller is the variance of interest payments (under perfect information they would issue long maturity debt). Investors, however, are uncertain about the type of government they face: a tough government may therefore want to issue short-term debt to avoid paying a premium on long maturities. This is because short-term debt is refinanced in period 1, after spending cuts are observed and thus, if the government is tough, at a lower interest rate.

Issuing short-term debt may also allow a tough government to distinguish itself from the weak type. We consider a class of separating equilibria where beliefs have the following form: for maturities shorter than or equal to $\mathrm{m}^{S}$, the separating maturity, investors expect the government to be tough; for maturities longer than $m^{S}$ they expect the government to be weak.

The weak government reveals itself if the expected loss when it chooses to issue only two-period bonds, and is therefore identified as weak, is smaller than the expected loss when it chooses a maturity equal to (or shorter than) $m^{S}$ :

$$
E_{0} L^{W}(W, m=1) \leq E_{0} L^{W}\left(T, m \leq m^{S}\right)
$$

\footnotetext{
${ }^{8}$ In principle, the spread, $s$, is a function of the difference in the probabilities of success faced by the two governments. Making $s$ endogenous, i.e. depend on the probabilities, $p$ 's, of the two governments, would certainly be desirable. However, this would prevent us from deriving analytical solutions while adding very little to our understanding of the problem.
} 
where the first term inside the parentheses denotes investors' beliefs. This inequality holds for

$$
m \leq m^{S} \equiv \frac{\sigma^{2}+s x-\sqrt{s^{2} x^{2}+\sigma^{2} s(2 x-s)}}{\sigma^{2}+s^{2}}
$$

where $x \equiv a+G^{H}+E_{0} r^{W}$ is the square root of the expected loss of the weak government under full information (divided by $\delta / 2$ ).

The incentive compatibility constraint of the weak government is satisfied for maturities lower than or equal to $m^{S}$ which can be shown to lie in the interval $[0 ; 1]$ for any choice of parameter values.

The intuition for this result is as follows. A short maturity brings no benefit to a weak government, except for allowing it to disguise itself as tough. Since by mimicking a tough government interest payments are saved only on long-term debt, such a gain disappears as the maturity shortens. By contrast, the refinancing risk increases with the amount of short-term debt issued. It follows that there is always a short enough, but positive, maturity, $0<m^{S}<1$, which makes the weak government reveal itself. Importantly, $m^{S}$ increases with the variance of interest rates, $\sigma^{2}$, and decreases with the informational spread, $s$, and thus with the level of the long term rate.

A separating equilibrium thus exists if the tough government is willing to shorten the maturity down to $m^{S}$, thus signaling its type. This happens if

$$
E_{0} L^{T}\left(T, m^{S}\right) \leq E_{0} L^{T}\left(W, m^{S}<\bar{m} \leq 1\right)
$$

where $\bar{m}$ is the maturity which minimizes the expected loss when the tough government is believed to be weak, that is, for maturities in the interval $\left[\mathrm{m}^{S} ; 1\right] .^{9}$

The incentive compatibility constraint of the tough government is satisfied if

$$
\left(1-m^{S}\right)^{2} \sigma^{2} \leq(1-\bar{m})^{2} \sigma^{2}+\bar{m}^{2} s^{2}+2 \bar{m} s z
$$

where $z \equiv a+G^{L}+E_{0} r^{T}$ is the square root of the expected loss of the tough government under full information (divided by $\delta / 2$ ).

This condition shows that the tough government will shorten the maturity of the debt only if the cost of being perceived as weak, which depends on the informational spread $s$, is high relative to the refinancing risk, $\sigma^{2}$.

A sufficient condition for a separating equilibrium is ${ }^{10}$

\footnotetext{
${ }^{9}$ Notice that if the tough government chooses a longer maturity than $m^{S}$, it opts for the maturity which minimizes its loss, given that it is believed to be weak. This maturity can be shorter than $m=1$ : a tough government believed to be weak issues some short-term bonds in order to minimize interest payments.

${ }^{10}$ The math is as follows. Since for any given maturity the expected loss is lower when the government is believed tough than when it is believed weak, condition (8) is satisfied for $\bar{m}=m^{S}$. Then, a suffficient condition, for (8) to hold, is that the loss from being believed weak increases with $m$ for maturities greater than $m^{S}$ : i.e. that $m^{2}\left(\sigma^{2}+s^{2}\right)-2 m\left(\sigma^{2}-s z\right)+z^{2}+\sigma^{2}$ increases over the interval $\left[m^{S} ; 1\right]$ which gives condition $(9)$.
} 


$$
\sigma^{2} \leq s\left(a+G^{L}+E_{0} r_{1}^{T}\right)\left(1+\frac{a+G^{L}+E_{0} r_{1}^{T}+s}{2\left(a+G^{H}+E_{0} r^{W}\right)-s}\right)
$$

where the right-hand-side is increasing in $s$.

Necessary conditions on the values of $\sigma^{2}$ and $s$ for the existence of a separating equilibrium can be found with the help of numerical simulations (they are not reported here). Results of such simulations confirm that $\sigma^{2}$ cannot be too large relative to $s$ -otherwise the tough government would prefer not to reveal itself, and limit the roll-over risk by issuing a larger amount of long-term debt. ${ }^{11}$

When a separating equilibrium does not exist, i.e. when the roll-over risk is high relative to the informational spread, pooling equilibria, where both governments choose the same maturity, may exist. ${ }^{12}$ We consider such equilibria in the next section.

\subsection{High risk and low cost: pooling equilibria}

We have shown that a committed government may issue short-term debt to signal its resolution to carry out the stabilization, and thus reduce the expected cost of debt service. Separating equilibria, however, may not exist when the informational spread is small relative to the refinancing risk.

In this section we examine pooling equilibria in which both governments choose the same maturity, and the interest rate on two-period bonds, i.e. the forward rate, is equal to

$$
E_{0} r_{1}^{P}=q E_{0} r_{1}^{T}+(1-q) E_{0} r_{1}^{W}=E_{0} r_{1}^{T}+(1-q) s
$$

where $q$, the probability that the government is tough, depends on the prior beliefs of investors. The forward rate decreases with a government's reputation, $q$, and increases with the informational spread, $s$.

Consider first maturities which minimize the loss functions of the two governments, given pooling expectations - more precisely, given that the interest rate on long-term debt is $E_{0} r_{1}^{P}$ as in a pooling equilibrium. A weak government will obviously prefer the longest possible maturity, $m=1$. This is because, on the fraction of short-term debt it issues, it will both pay a higher rate when such debt is refinanced, and be exposed to refinancing risk. The loss of a weak government is thus decreasing in debt maturity. On the contrary, a tough government finds it optimal to issue some shortterm debt, even in the absence of signaling effects, since such debt is refinanced after spending cuts are observed and, thus, at an interest rate that is lower than $E_{0} r_{1}^{P}$. Given a 'pooling' interest rate on two-period bonds equal to $E_{0} r_{1}^{P}$, the maturity, $m^{T}$,

\footnotetext{
${ }^{11}$ The results of these simulations are available from the authors upon request.

${ }^{12} \mathrm{It}$ is worth noting that pooling equilibria may also exist for values of $\sigma^{2}$ and $s$ which admit separating equilibria.
} 
which minimizes the loss of the tough government, is equal to

$$
m^{T}=\frac{\sigma^{2}-(1-q) s z}{\sigma^{2}+(1-q)^{2} s^{2}}
$$

It follows that a pooling equilibrium cannot be supported by pooling expectations for maturities longer than $m^{T}$ : in this case a weak government would choose a longer maturity than a tough one, and a pooling equilibrium would not exist.

We consider a class of pooling equilibria where beliefs are as follows: for maturities shorter than or equal to $m^{T}$ — the pooling maturity - investors do not distinguish the government type and ask for an interest rate on two-period bonds equal to $E_{0} r_{1}^{P}$; for maturities longer than $m^{T}$ they expect the government to be weak.

With these expectations the tough government chooses $m^{T}$, since this maturity minimizes its expected loss. ${ }^{13}$ Therefore, a pooling equilibrium, where both governments choose the same maturity $m^{T}$, exists if $m^{T}$ satisfies the incentive compatibility constraint of the weak government:

$$
E_{0} L^{W}\left(\text { Pooling, } m^{T}\right) \leq E_{0} L^{W}(W, m=1)
$$

which holds for

$$
m^{T}=\frac{\sigma^{2}-(1-q) s z}{\sigma^{2}+(1-q)^{2} s^{2}} \geq m^{W}=\frac{\sigma^{2}+s q x-\sqrt{s^{2} q^{2} x^{2}+\sigma^{2} s q(2 x-s q)}}{\sigma^{2}+s^{2} q^{2}}
$$

where we have used the definition of $m^{T}$ from equation (11).

Condition (12) shows that for a weak government the pooling maturity, $m^{T}$, must be sufficiently long (i.e. greater than $m^{W}$ ) to insulate the budget from refinancing risk and produce a large enough reduction in interest costs. Moreover, condition (12) shows that for a pooling equilibrium to exist the initial reputation, $q$, must be sufficiently high. Intuitively, a better reputation implies a lower informational premium, $(1-q) s$, thus making the tough government willing to choose a longer maturity, $m^{T}$. A better reputation also decreases the maturity $m^{W}$ that makes the weak government indifferent between choosing $m^{T}$ or $m=1$, thus revealing itself. This is because, as $q$ increases, long-term debt becomes cheaper: this increases the incentive of a weak government not to reveal itself and face a higher refinancing risk.

Other pooling equilibria may exist when $m^{T}>m^{W}$. In particular, it can be shown that any maturity $m^{P}$, such that $m^{W} \leq m^{P}<m^{T}$ can also be sustained as a pooling equilibrium by the expectation that the government is weak when a maturity longer than $m^{P}$ is chosen, provided that $m^{P}$ satisfies the incentive compatibility constraint of the tough government. ${ }^{14}$

\footnotetext{
${ }^{13}$ Note that for any given maturity the loss of the tough government under pooling is lower than the loss when it is believed weak.

${ }^{14}$ The interested reader is referred to Missale, Giavazzi and Benigno (1997).
} 
Although the parameter values for which condition (12) holds cannot be derived analytically, the important points for the empirical analysis that follows can be made without numerical simulations. First, if a pooling equilibrium exists, the corresponding maturity is longer than the separating maturity $m^{S}$ which induces a weak government to reveal itself. ${ }^{15}$ Second, the maturities $m^{W}$ and $m^{T}$-and thus any pooling maturity - increase with the variance of period 1 interest rates, $\sigma^{2}$, and decreases with the informational spread, $s$.

\subsection{Empirical predictions}

The analysis of the previous sections suggests that the share of long-term debt should increase with the volatility of short-term interest rates and decrease with the informational spread. We have shown that, when the variance of short-term rates, $\sigma^{2}$, is low relative to the spread, $s$, a separating equilibrium exists; the separating maturity, $m^{S}$, increases with $\sigma^{2}$ and decreases with $s$ as described by equation (7). Instead, for higher values of $\sigma^{2}$ relative to $s$ only pooling equilibria may exist. In a pooling equilibrium debt maturity is always longer than in a separating equilibrium. Moreover, the pooling maturity increases with $\sigma^{2}$ and decreases with $s{ }^{16}$

To summarize: the proportion of long-term debt that governments issue during fiscal stabilizations should increase with the variance of short-term interest rates and decrease with the informational spread, namely, with the difference between the longterm interest rate and the government's expectations of future short-term interest rates. Indeed, a higher volatility of interest rates implies a greater refinancing risk which can be avoided by issuing long-term debt. On the other hand, when long-term interest rates are high relative to government's expectations of future rates, because of the private sector's lack of confidence in the authorities' ability to cut spending, the government can reduce debt servicing costs by issuing short-term debt until the time when credibility is gained and long-term rates decline.

\footnotetext{
${ }^{15}$ This follows by noting that $m^{S}$ is implicitly defined by $\left(m^{S}\right)^{2}\left(\sigma^{2}+s^{2}\right)-2 m^{S}\left(\sigma^{2}+s x\right)+\sigma^{2}=0$. Substituting the value of $m^{S}$ in the loss differential of the weak government yields:

$$
E_{0} L^{W}\left(\text { Pooling, } m^{S}\right)-E_{0} L^{W}(W, m=1)=m^{S} s(1-q)\left[2 x-(1+q) m^{S} s\right]>0
$$

which shows that $m^{S}$ does not satisfies the incentive compatibility constraint of the weak government and therefore that $m^{S}<m^{W}$.

${ }^{16} \mathrm{It}$ is, however, worth noting that for certain values of $\sigma^{2}$ and $s$ the equilibrium could be pooling or separating, implying that different maturities might be observed for the same parameter values. In this case the use of refinements is necessary to eliminate pooling equilibria and thus fully prove our claim.
} 


\section{Debt maturity and fiscal stabilizations: the evidence}

In this section we test the predictions of our theory using cross-sectional data on the composition of public debt and on interest rates in 72 episodes of fiscal stabilization occurred in the OECD countries between 1975 and 1998. We have identified these episodes using the OECD estimates of the general government's primary structural budget surplus - that is, the cyclically adjusted budget surplus net of interest payments (see the Appendix for further details). An episode of fiscal stabilization is defined as a period, lasting one or more years, during which the structural primary surplus improves by at least 1 percent of GDP. This definition is intended to capture relatively important changes in the discretionary component of the budget. By excluding very small corrections - those between 0 and 1 percent of GDP - we avoid the risk of including improvements in the primary budget which occurred by chance, or simply because of the exhaustion of temporary expansionary measures. More importantly, we want to capture relatively large fiscal corrections, since the predictions of our model concern the issuing strategy of governments confident in their ability to implement the announced program. ${ }^{17}$

The regression we run is of the form

$$
m_{t+1}-m_{t-1}=\beta_{0}+\beta_{1}\left(\sigma_{r} / \mu_{r}\right)_{t-1}+\beta_{2} R_{t-1}+\beta_{3} \Delta R_{t}+\beta_{4} m_{t-1}+\beta_{5}(B / G D P)_{t-1}+\varepsilon
$$

where $m_{t+1}-m_{t-1}$, is the two-year change in the share of fixed-rate long-term debt; $\left(\sigma_{r} / \mu_{r}\right)_{t-1}$ is the conditional standard error (divided by the mean) of short-term interest rates; $R_{t-1}$ is the long-term interest rate the year before the stabilization; $\Delta R_{t}$ is the change in the long-term interest rate in the first year of the stabilization; $m_{t-1}$ is the initial share of long-term debt and $(B / G D P)_{t-1}$ is the initial debt-to-GDP ratio.

The two-year change in the share of fixed-rate long-term debt is computed as the difference between the share of such debt at the end of the second year of the stabilization and the share at the end of the year preceding the stabilization. ${ }^{18}$ The share of fixed-rate long-term debt is defined as the percentage of fixed-rate government bonds and loans denominated in the domestic currency with an initial maturity longer than one year (see the Appendix for further details). Consistently with our model, floating-rate bonds are defined as short maturity debt since their coupons reflect (with a lag) changes in market interest rates. Floating-rate debt thus exposes the budget to refinancing risk as much as short maturity debt and, similarly, it allows the government to reduce debt servicing costs in the event of a fall in interest rates. The

\footnotetext{
${ }^{17}$ However, by selecting large fiscal corrections we miss evidence on adjustments which turned out to be small contrary to expectations.

${ }^{18}$ For most countries in our sample this information is available only once-a-year, at the end of the fiscal year, usually December 31st. For countries where the fiscal year ends on March 31st data have been assigned to December of the previous year.
} 
classification of bonds and loans denominated in foreign currency, and of inflationindexed bonds, is less clear cut. If high long-term interest rates reflect expected inflation and exchange-rate depreciation, then indexed and foreign-currency debt play the same role as short-term debt, since they reduce the cost of borrowing and signal commitment. ${ }^{19}$ Including such instruments in short maturity debt would instead be wrong if high interest rates reflected a premium arising from default risk. Although such a case seems unlikely for the sample of industrialized OECD countries, and for the period considered in our estimation, we also report the results obtained when such instruments are included among long-term debt. ${ }^{20}$

The specification of equation (13) is suggested by the model presented in Section 2. Three factors influence the government's choice of debt maturity at the start of a stabilization: the roll-over risk, the informational spread and the credibility of the government.

The roll-over risk depends on the variance of short-term interest rates, as expected by the debt manager, and is thus conditional on her information. We proxy the conditional variance by the standard error (divided by the mean) of short-term interest rates in the seven-year period preceding the stabilization. The standard error is estimated from an auxiliary regression (on quarterly data) of the short-term rate on its first lag and the first lag of the long-term rate.

Measuring the informational spread is difficult because debt managers' expectations of future interest rates (which reflect their private information) are not observable. The relevant theoretical variable is the difference between the forward rate implicit in the long-term interest rate (i.e. the expectation of future interest rates implied by the term structure) and the forward rate as expected by the debt manager: $E_{0} r_{1}-E_{0+}^{T} r_{1}$, where the superscript $\mathrm{T}$ denotes the government's expectation (here assumed to be of the tough type) taken over an information set which includes its private information about the level of government spending in period 1, and is thus larger than that of investors. We use the level of the long-term interest rate at the start of each episode, $R_{t-1}$, to proxy for the informational spread, implicitly assuming that the expectations of debt managers on the level of future interest rates are constant across fiscal stabilization episodes. This would be the case if debt managers shared a common view about what the interest rate will be after a successful

\footnotetext{
${ }^{19}$ Although such instruments reduce the roll-over risk, they expose the government budget to other risks and costs. For instance, foreign currency debt introduces exchange-rate risk stemming from foreign monetary disturbances (see Bohn 1990 and Miller 1997b), while indexed debt could be costly to issue since a market for such debt may not exist or be illiquid (see Townend 1997 and Persson 1997).

${ }^{20}$ Changes in the composition of the debt also reflect government interventions in the secondary market, designed to modify the interest-rate sensitivity of debt servicing costs. In practice, the authorities' operations are often limited to the primary market: this would suggest using the share of long-term debt in total issues as an alternative dependent variable. We have not explored this because the data are not available.
} 
stabilization. It is worth noting that conventional measures of credibility, such as the spread between long- and short-term interest rates, i.e. the slope of the yield curve, are not appropriate for the problem we are considering. What matters is not the current level of the short-term rate, but rather the future level of such rate, as expected by the debt manager, compared with the market's expectations implicit in the current long-term rate. In fact, the issuing strategy of a debt manager facing a flat yield curve can be quite different depending on whether the level of the interest rate is 5 or 15 percent.

Measuring the credibility of a stabilization program is also difficult. Ideally, one would like to know how credible is the program at the time it is announced, before the maturity of the debt is chosen. The credibility of the stabilization plan could then be measured by the change in the long-term interest rate at the time of the announcement. Recovering such information from case studies of individual stabilizations requires too much of an effort and may not solve the problem. A sudden fall in interest rates is rarely observed at the time of the announcement: more often credibility builds up gradually along with the implementation of fiscal measures. Realistically, we have to rely on an ex-post measure of credibility. We proxy credibility with the change in the long-term interest rate that occurs during the first year of the stabilization. We expect, consistently with the argument developed in the previous sections, that a fall in the long-term rate leads the debt manager to issue long-term debt, and thus increases the share of such debt.

Finally, we add two control variables to the set of regressors: the initial share of long-term debt and the debt-to-GDP ratio at the start of the stabilization episode. We include the initial share of long-term debt since the model presented in this paper does not claim to provide a complete account of the steady-state composition of the debt. For instance, we expect a correction towards a higher share of long debt (a negative coefficient on the initial share) in countries which start from a very low level of long-term debt. Indeed, in such countries debt managers should be motivated by a relatively greater concern for refinancing risk.

The initial level of debt relative to GDP may also affect the behavior of debt managers, in the sense that objectives, such as cost and risk minimization, should be relatively more important in highly indebted countries. Furthermore, Missale and Blanchard (1994) and De Broeck (1997) have found evidence of a negative relation between the debt ratio and the share of long-term debt over time within single countries. 


\subsection{Empirical results}

The 72 episodes of fiscal corrections we consider are listed in Table $1 .{ }^{21}$ The composition of the public debt in each country is obtained from national sources and is reported in Missale (1999). Data on debt, short- and long-term interest rates are from OECD Economic Outlook. Long-term interest rates refer to the yields-to-maturity of benchmark long-term government bonds on the domestic market. Short-term interest rates refer to 3-month interbank rates. ${ }^{22}$ Quarterly data on short-term interest rates used to estimate $\sigma_{r} / \mu_{r}$ are from OECD Main Economic Indicators (see the Appendix for further details).

No clear pattern in the choice of debt maturity emerges from Table 1 . While on average the share of long-term debt slightly increases the number of episodes where the opposite happens appear to be equally important.

In Table 2 we report the results of the OLS estimation of equation (13). The estimates for the full sample of stabilization episodes are shown in column 1. The coefficient on the standard error of the short-term interest rate is positive and significant at the $10 \%$ level, suggesting that an increase in the volatility of short rates leads debt managers to issue more long-term debt in order to limit the refinancing risk. The coefficients on the long-term interest rate and its change are negative as expected, and significant at the $5 \%$ level. This result strongly supports the prediction that a lack of confidence in the fiscal correction on the part of investors - as reflected in a relatively high long-term rate - leads governments to issue short-term debt (or variable rate or foreign-currency debt) in order to avoid being locked into costly debt contracts. An increase in long-term rates during the first year of the program, an indication that the program is not credible, also significantly reduces the share of long-term debt. Finally, the effect of the initial share of long-term debt is negative and significant: as expected, a low initial share of long-term debt is associated with an increase in such debt. The debt-ratio appears to positively affect the share of long-term debt but its coefficient is unprecisely estimated.

In the next columns of Table 2 we ask whether the effects detected so far are equally present in the sub-sample of episodes characterized by a relatively larger, or more protracted, fiscal adjustment. ${ }^{23}$ Column 2 presents evidence for episodes of fiscal

\footnotetext{
${ }^{21}$ According to our definition, there are 79 episodes of fiscal correction from 1975 to 1998 for the 19 countries for which the OECD Economic Department estimates structural balances (see OECD Economic Outlook, Annex Table 31). Our sample reduces to 72 episodes due to the lack of information on the debt composition of Greece and Norway and because data on interest rates for the Spanish episode of 1975 are not available.

${ }^{22}$ Interest rates on 3 -month Treasury bills are not available for all countries. For long-term rates the OECD Economic Outlook reports the yield-to-maturity on 10-year bonds when available, otherwise it considers shorter maturity bonds.

${ }^{23}$ Giavazzi and Pagano (1996) find that fiscal stabilizations that are larger and last longer, affect expectations differently, compared with less sizeable programs.
} 
adjustments greater or equal to $2 \%$ of GDP (Corr $\geq 2)$. We have no good excuse for choosing the $2 \%$ cut-off point, except that any such choice would be arbitrary, and the consideration of larger corrections would leave us with too few observations. In the restricted sample of 51 episodes both the level and the change of the long-term rate continue to be highly significant, as well as the initial share of long-term debt. The result for the standard error of short-term rates is however stronger in the new sample, as its coefficient is now significant at the $5 \%$ level. The fit of the regression also improves.

In column 3 we examine the implications of making our definition of fiscal correction more restrictive along the time dimension. We continue to consider fiscal adjustments greater or equal to $2 \%$ of GDP but further restrict the sample to episodes which last two or more years (Corr $\geq 2$, Dur $\geq 2 y$ ). This provides evidence on stabilizations that are significant because of the consistent changes in the discretionary component of the budget deficit, in addition to their overall magnitude. The experiment leads to similar results as those shown in column 2. This outcome is not surprising given that the sample is reduced by only seven episodes (most episodes of large fiscal corrections last two or more years). In what follows we thus forget about episodes characterized by $D u r \geq 2 y$, and report only the results obtained from the two larger samples.

We next focus on the 44 episodes where the initial level of debt is greater than $50 \%$ of GDP, in order to examine how the level of debt affects debt management. The evidence reported in column 4 shows that at high levels of debt the choice of debt instruments becomes more sensitive to long-term interest rates, while the conditional variance of short-term rates no longer affects the issuing policy. Although this result is difficult to interpret within our model, it suggests that, at high levels of debt, cost considerations and credibility effects become more important than interest-rate volatility for the success of the stabilization program.

Next we address a possible objection to the approach we followed so far: the definition of long-term debt. As discussed above, our definition of foreign currency debt and inflation-indexed debt as short-term debt is appropriate if high interest rates mainly reflect a lack of confidence in the government's ability to put prices and the exchange rate under control. On the contrary, if interest rates reflected high default-risk premia, then foreign currency debt and indexed debt should be classified according to their maturity.

In columns 5 to 8 of Table 2 we provide evidence on a definition of long-term debt which includes debt denominated in foreign currencies. ${ }^{24}$ Interestingly, the new definition of long-term debt appears to be uncorrelated with the standard error of

\footnotetext{
${ }^{24}$ Since the maturity composition for the debt denominated in foreign currencies is available only for few countries, we had to include maturities shorter than one year. However, for countries where the information is available, short maturities appear to be a minor component of foreign debt. The classification of inflation-indexed debt matters only for few recent Australian and UK episodes and thus does not affect the result.
} 
short-term rates. The relation with the level of the long-term rate is also weak: the corresponding coefficient is significant only for the full sample, and only at the $10 \%$ level. We take such evidence as a clear indication that in most episodes foreign currency debt played the same role as short maturity debt. ${ }^{25}$

In Table 3 we examine whether the spread between long- and short-term interest rates, $\left(R_{t-1}-r_{t-1}\right)$ and its change, $\Delta\left(R_{t}-r_{t}\right)$, better explain the behavior of debt managers during stabilization attempts than the variables suggested by our model. Controlling for the spread between long and short rates serves two purposes. First, it helps to distinguish our credibility story from other hypotheses about the behavior of debt managers. In particular, we want to explore the possibility that the reaction of debt managers to long rates just follows from a 'naive' strategy of borrowing short when long rates are high relative to short rates, and vice versa. This strategy might be suggested by a failure of the expectations hypothesis of the term structure of interest rates of the kind shown by Campbell (1995) for the U.S. ${ }^{26}$ Second, the longshort spread is a commonly used measure of credibility. It is commonly held that the slope of the yield curve not only conveys useful information about the path of future interest rates but also captures "unjustified" inflation expectations or risk premia to which debt managers may want to react.

In columns 1 to 3 of Table 3 the long-short spread $\left(R_{t-1}-r_{t-1}\right)$ in the year preceding the stabilization attempt and its change, $\Delta\left(R_{t}-r_{t}\right)$, during the first year of the stabilization have been added to the set of regressors. The results are striking: the coefficient on the basic explanatory variables are unaffected. Not only the long rate and its change outperform the long-short interest-rate spread and its change, but the coefficient on the spread is positive and significant. Contrary to what expected, a steep yield curve is associated with an increase in the share of long-term debt. A change in the spread has also a positive impact on the share of long-term debt. In the full sample such effects are significant at the $5 \%$ level as shown in column 1 . The long-short spread and its change, however, are not significant in the case of large fiscal adjustments, as shown in column 2. This evidence provides a strong rejection of the 'naive' hypothesis about debt managers' behavior, as they seem to issue more long-term debt when long rates are high relative to short rates.

The results in Table 3 suggest that what matters for debt managers' decisions is the level of the long-term interest rate (relative to their expectations), while the position of short rates is not that important. For example, a debt manager facing high short and long interest rates, with short rates higher than long rates, may well

\footnotetext{
${ }^{25}$ Applying different definitions of long-term debt denominated in domestic currency, in particular excluding fixed-rate loans or limiting the attention to the debt held by the private sector, where possible, does not significantly affect the results.

${ }^{26}$ Campbell shows that in the U.S. borrowing short at times when the slope of the yield curve is steeper than normal (and viceversa) would allow substantial savings in debt servicing costs. This is likely to happen because term premia on long-term bonds increase with the slope of the yield curve.
} 
prefer to borrow short if she is confident that long rates are temporarily high, and will fall as the program is carried out and credibility builds up. In fact, a rationale could be found even for the positive relation between the share of long-term debt and the slope of the yield curve. Stabilization episodes are often accompanied by a tightening of monetary policy which raises short rates above long rates. In such instances the yield slope becomes negative, and the credibility of the stabilization attempt can only be inferred from the behavior of the long rate. ${ }^{27}$ Only the fall in such rate below its pre-stabilization level, rather than the twist in the yield curve, can signal that the stabilization is credible.

Finally, we ask whether our estimates may suffer from an endogeneity problem. As we measure the credibility of the stabilization by the fall in the interest rate during the first year of the program, there is a potential for this variable to be affected by the type of debt that the government issues at the outset of the stabilization. The choice of debt instruments may convey private information about the prospects of the stabilization, and may thus affect private sector's expectations and interest rates. To deal with this potential source of endogeneity in the change in the long-term interest rate, we use, as an instrument, the change in such variable occurred in the six months preceding the first year of the stabilization attempt.

Instrumental variable estimates are shown in columns 4 to 6 of Table 3. These regressions generally confirm the OLS results. The coefficient on the long-term interest rate is unaffected. The impact of the standard error of short-term rates is instead stronger in all samples considered, and is significant at the $5 \%$ level both for the full sample and for adjustments larger than $2 \%$ of GDP. Finally, the coefficient on the change of long-term debt remains significant at the $5 \%$ level in all the regressions considered. Although, this coefficient is greater (in absolute value) than the corresponding OLS coefficient, a formal Hausman test does not reject the hypothesis that such variable is exogenous to the choice of debt maturity at the $10 \%$ significance level for all samples.

Overall the impression is that our theory provides a consistent explanation of debt managers' behavior in OECD economies over the last three decades. Our basic regression accounts for more than one fourth of the observed change in the share of long-term debt, a result which is even more comforting if we consider that it has been obtained from data covering a long spell of time and different institutional arrangements, monetary and exchange-rate regimes. This result should also be contrasted with the lack of a systematic relation between changes in the debt composition and interest rates over time within single countries (see e.g. Missale 1999).

\footnotetext{
${ }^{27}$ This is particularly evident for the European countries members of the Exchange Rate Mechanism of the EMS, as defenses of the fixed parity were often accompanied by fiscal adjustments.
} 


\section{Concluding remarks}

When a stabilization plan is announced, it typically does not enjoy full credibility among investors: long-term interest rates are thus higher than policymakers' expectations of future rates. This feature of a stabilization allows to overcome a common problem in the analysis of debt management - namely that policymakers' expectations of interest rates are not observable.

Studying fiscal stabilizations in OECD countries, we find evidence that governments do issue a larger share of short-term debt the higher is the interest rate on long-term bonds and the lower is the variance of short-term interest rates. We fail, instead, to find evidence in favor of the common view that the choice of debt maturity is affected by the spread between long- and short-term interest rates: divergences of government's views from market expectations seem to provide a better explanation of government behavior. In other words, debt managers appear to be driven more by their expectations about the future evolution of interest rates than by the attempt to exploit failures in the expectations hypothesis of the term structure, in particular, systematic variations in term premia. This behavior is consistent with evidence that the expectations hypothesis of the term structure performs reasonably well in European countries, which represent the main group in our sample (see e.g. Hardouvelis 1994, Gerlach and Smets 1998). It is also consistent with evidence for the U.K. that strategies based on the minimization of term premia yield negligible savings in interest costs (see Coe, Pesaran and Vahey 2000).

Finally, our findings cast doubts on the relevance of debt management theories which stress the strategic use of debt instruments (see e.g. Milesi-Ferretti 1995, Uhlig 1997, Pecchi and Piga 1999). In particular, governments do not appear to issue long maturity debt in order to increase bondholders' political support for anti-inflationary policy and fiscal restraint. The evidence in this paper points instead to a conventional trade-off between the cost and risk of debt service, as usually stated in the reports of debt agencies. Such a trade-off appears a key element of how debt is actually managed and should provide the starting point of a positive theory of debt management. 


\section{References}

Alesina, A., Prati, A. and Tabellini, G. (1990). 'Public confidence and debt management: a model and a case study of Italy.' In Public Debt Management: Theory and History, (eds. R. Dornbusch and M. Draghi), pp. 94-124. Cambridge: Cambridge University Press.

Barro, R. J. (1995). 'Optimal debt management.' NBER Working Paper 5327. Printed as 'Optimal funding policy.' In The Debt Burden and its Consequences for Monetary Policy, (eds. G. Calvo and M. King), pp. 69-81 IEA Conference Volume no. 118. London: Macmillan Press Ltd., 1998.

Barro, R. J. (1997). 'Optimal management of indexed and nominal bonds.' NBER Working Paper 6197.

Bohn, H. (1990). 'A positive theory of foreign currency debt.' Journal of International Economics, vol. 29, pp. 273-92.

Calvo, G. A. (1988). 'Servicing the public debt: the role of expectations.' American Economic Review, vol. 78(4), pp. 647-61.

Calvo, G. A., Guidotti, P. E. and Leiderman, L. (1991). 'Optimal maturity of nominal government debt: the first tests.' Economic Letters, vol. 35, pp. 415-21.

Campbell, J. Y. (1995). 'Some lessons from the yield curve.' Journal of Economic Perspectives, vol. 9, Summer, pp. 129-52.

Coe, P. M. Pesaran, H. and Vahey, S. P. (2000). 'The cost efficiency of UK debt management: a recursive modelling approach.' Mimeo, April.

De Broeck, M. (1997). 'The financial structure of government debt in OECD countries: an examination of the time-consistency issue.' Journal of Monetary Economics, vol. 39, pp. 279-301.

Dornbusch, R. (1991). 'Credibility and stabilization.' Quarterly Journal of Economics, vol. CVI, no. 426, pp. 837-50.

Drazen, A. and Masson, P. R. (1994). 'Credibility of policies versus credibility of policymakers.' Quarterly Journal of Economics, pp. 735-54.

Giavazzi, F. and Pagano, M. (1990). 'Confidence crises and public debt management.' In Public Debt Management: Theory and History, (eds. R. Dornbusch and M. Draghi), pp. 94-124. Cambridge: Cambridge University Press.

Giavazzi, F. and Pagano, M. (1996). 'Non-Keynesian effects of fiscal policy: more international evidence and the Swedish experience.' Swedish Economic Policy Review, vol. 3, no. 1.

Gerlach, S. and Smets, F. (1998). 'Exchange Rate regimes and the expectations hypothesis of the term structure.' In Monetary Policy and Interest Rates, (eds. I. Angeloni and R. Rovelli), pp.11-35. London and New-York: Macmillan and S.Martin.

Hardouvelis, G. A. (1994). 'The term structure spread and future changes in long and short rates in the G-7 countries: is there a puzzle?' Journal of Monetary Economics, vol. 33, pp. 255-83. 
H.M. Treasury and Bank of England, (2000). Debt Management Report 2000-01. London: H.M. Treasury. (www.dmo.gov.uk)

Instituto de Gestão do Crédito Público (2000). Government Debt Management: Annual Report of 1999, Portugal, Lisbon: IGCP. (www.igcp.pt)

Milesi-Ferretti, G. M. (1995). 'Do good or do well? Public debt management in a two party economy.' Economics and Politics, vol. 7(1), pp. 59-78.

Miller, V. (1997a). 'Political instability and debt maturity.' Economic Inquiry, vol. 35(1), pp. 12-27.

Miller, V. (1997b). 'Why a government might want to consider foreign currency denominated debt.' Economics Letters, vol. 55(2), pp. 247-50.

Ministry of Finance (2000). Public Debt: Annual Report 1999, Bruxelles: Ministry of Finance, Kingdom of Belgium. (www.treasury.fgov.be)

Missale, A. (1997). 'Managing the public debt: the optimal taxation approach.' Journal of Economic Surveys, vol. 11(3), pp. 235-65.

Missale, A. (1999). Public Debt Management. Oxford: Oxford University Press.

Missale, A. and Blanchard, O. J. (1994). 'The debt burden and debt maturity.' American Economic Review, vol. 84(1), pp. 309-19.

Missale, A., Giavazzi, F. and Benigno, P. (1997). 'Managing the public debt in fiscal stabilizations: the evidence.' NBER Working Paper 6311.

Obstfeld, M. (1994). 'The logic of currency crises.' Cahiers Economiques et Monètaires (Banque de France), No.43. Abridged version reprinted in Monetary and Fiscal Policy in an Integrated Europe, (eds. B. Eichengreen, J. Frieden and J. von Hagen), pp. 62-90, New York: Springer.

Pecchi, L. and Piga, G. (1999). 'The politics of index-linked bonds.' Economics and Politics, vol. 12(2), pp. 201-212.

Persson, M. (1997). 'Index-linked bonds: the swedish experience.' In Managing Public Debt: Index-Linked Bonds in Theory and Practice, (eds. M. De-Cecco, L. Pecchi and G. Piga), pp. 18-32. Cheltenham: Edward Elgar.

Sachs, J. Tornell, A. and Velasco, A. (1996). 'The Mexican Peso crisis: sudden death or death foretold.' Journal of International Economics, vol. 41, pp. 265-83.

Townend, J. (1997). 'Index-linked government securities: the UK experience.' In Managing Public Debt: Index-Linked Bonds in Theory and Practice, (eds. M. De-Cecco, L. Pecchi and G. Piga), pp. 1-17. Cheltenham: Edward Elgar.

Swedish National Debt Office (2000). Annual Report 1999. Stockholm: SNDO. (www.rgk.se)

Uhlig, H. (1997). 'Long term debt and the political support for a Monetary Union.' CEPR Discussion Paper no. 1603. 


\section{Appendix: Data Sources and Definitions}

Data on primary structural surpluses as a percentage of actual GDP have been computed by normalizing structural balances (defined in terms of potential GDP) and subtracting interest payments as a percentage of actual GDP. (The latter are obtained as the difference between overall financial surpluses and the corresponding primary surpluses). For the most recent period these data are published in the OECD Economic Outlook. Revised series of the above variables starting in 1970s have been kindly provided by Alexandra Bibbe of the OECD Economics Department, Public Economics Division.

Data on the composition, by instrument, of public debts are from national sources and are reported in Missale (1999). Usually they refer to the Central Government debt, but the rule is amended in a few cases when data are available only for the General Government. Since for some countries the composition of debt holdings of the monetary authorities is not available, we use a definition of debt which includes Central Bank holdings, net of credit lines.

Long-term debt is defined as the sum of fixed-rate bonds and loans denominated in the domestic currency with an initial term to maturity longer than one year. This rule is amended for Spanish and Italian Treasury bills with an 18-months maturity that have been considered as short maturity debt.

Hence, bonds and loans denominated in foreign currency, and bonds bearing coupons indexed to market interest rates, to the price level, or to the ECU exchange rate, have been considered as short-term debt.

Long-term Spanish loans of the 1970s have been considered as short debt, since they were placed with the local banks at below-market interest rates.

Extendible bonds and bonds with an option for early redemption (such as those issued in Belgium, France and Italy) have been considered as long-term debt if the period preceding the earliest possible maturity is longer than one year. Fixed-rate bonds with an option for converting coupons into variable-rate coupons (as those issued in France in the early 1980s) have been considered as fixed-rate debt since the holders do not exercise the option in case the interest rate falls.

Long-term interest rates refer to the yields-to-maturity of benchmark long-term government bonds on the domestic market. Short-term interest rates refer to 3-month interbank rates, since interest rates on Treasury bills are not always available.

Yearly data on short- and long-term interest rates are from OECD Economic Outlook. Quarterly data on short- and long-term interest rates are from OECD Main Economic Indicators and, when the OECD series is not available, from IMF International Financial Statistics.

The ratio of public debt to GDP is from OECD Economic Outlook and refers to gross general government debt. 
Table 1: The Stabilization Episodes in our Sample

\begin{tabular}{|c|c|c|c|c|c|c|c|c|c|}
\hline Episode & Corr & $m_{t+1}-m_{t-1}$ & $m_{t-1}$ & $B / G D P$ & $\sigma_{r} / \mu_{r}$ & $R_{t-1}$ & $R_{t-1}-r_{t-1}$ & $\Delta R_{t}$ & $\Delta\left(R_{t}-r_{t}\right)$ \\
\hline Austral 77 & 2.7 & -12.6 & 70.1 & 24.5 & 11.0 & 10.2 & 0.9 & 0.1 & -0.9 \\
\hline Austral 80-82 & 3.2 & 1.7 & 56.1 & 25.4 & 7.0 & 9.8 & -0.1 & 1.9 & -0.4 \\
\hline Austral 85-88 & 3.7 & -5.9 & 64.5 & 25.4 & 6.7 & 13.6 & 1.3 & 0.4 & -3.6 \\
\hline Austral 95-98 & 3.1 & -1.8 & 76.3 & 35.8 & 7.7 & 9.0 & 3.3 & 0.2 & -1.8 \\
\hline Austria 77-78 & 2.0 & 2.6 & 53.9 & 27.4 & 2.1 & 8.8 & 4.1 & 0.0 & -2.8 \\
\hline Austria 80-81 & 2.3 & -14.3 & 60.6 & 36.0 & 1.6 & 8.0 & 2.4 & 1.4 & -3.3 \\
\hline Austria 84 & 2.2 & -1.0 & 41.9 & 46.5 & 1.9 & 8.2 & 2.8 & -0.2 & -1.3 \\
\hline Austria 92 & 1.4 & 2.5 & 48.7 & 58.6 & 6.2 & 8.6 & -0.5 & -0.3 & -0.6 \\
\hline Austria 96-97 & 3.3 & 6.4 & 54.6 & 69.2 & 4.2 & 7.1 & 2.5 & -0.8 & 0.4 \\
\hline Belgium 77 & 1.3 & -1.2 & 80.2 & 59.4 & 21.8 & 9.1 & -0.8 & -0.3 & 2.5 \\
\hline Belgium 82-87 & 10.0 & -6.6 & 55.1 & 92.9 & 20.0 & 13.4 & -1.8 & 0.0 & 1.3 \\
\hline Belgium 92-94 & 3.5 & 2.7 & 59.4 & 130.3 & 9.2 & 9.3 & -0.1 & -0.7 & -0.6 \\
\hline Belgium 96-98 & 1.3 & 2.2 & 60.3 & 134.6 & 13.7 & 7.6 & 2.5 & -0.8 & 0.2 \\
\hline Canada 79-81 & 3.3 & 9.3 & 39.8 & 46.4 & 12.3 & 9.3 & 0.4 & 0.9 & -2.3 \\
\hline Canada 86-90 & 3.2 & 1.0 & 40.2 & 64.7 & 17.4 & 11.1 & 1.5 & -1.6 & -1.2 \\
\hline Canada 93-98 & 7.6 & 4.0 & 46.1 & 88.0 & 11.9 & 8.8 & 2.1 & -0.9 & 0.8 \\
\hline Denmark 83-86 & 12.2 & 8.2 & 59.3 & 67.0 & 17.9 & 21.4 & 4.6 & -6.3 & -2.2 \\
\hline Denmark 96-98 & 1.7 & 11.0 & 60.8 & 80.9 & 17.1 & 8.3 & 2.3 & -1.2 & 1.0 \\
\hline Finland 75-76 & 3.7 & -10.0 & 57.0 & 8.5 & 3.5 & 8.8 & -1.6 & 0.8 & -0.5 \\
\hline Finland 81 & 1.3 & -4.6 & 42.2 & 14.1 & 12.4 & 10.4 & -1.9 & 0.6 & 1.3 \\
\hline Finland 84 & 2.4 & -1.9 & 43.0 & 18.5 & 9.4 & 10.8 & -3.8 & 0.4 & -1.6 \\
\hline Finland 88-89 & 2.4 & 10.6 & 45.8 & 20.5 & 7.6 & 7.9 & -2.1 & 2.4 & 2.5 \\
\hline Finland 93-94 & 1.8 & 3.5 & 30.9 & 46.2 & 11.5 & 12.1 & -1.2 & -3.8 & 1.6 \\
\hline Finland 96-97 & 2.3 & 12.0 & 43.4 & 69.0 & 14.7 & 8.0 & 2.2 & -0.7 & 1.5 \\
\hline France 76 & 1.2 & -2.0 & 16.3 & 30.4 & 14.7 & 10.3 & 2.4 & 0.2 & -0.6 \\
\hline France $79-80$ & 2.5 & 12.9 & 15.2 & 31.0 & 12.9 & 10.6 & 2.5 & 0.2 & -1.1 \\
\hline France $83-87$ & 3.4 & 1.4 & 30.1 & 34.2 & 11.0 & 16.0 & 1.4 & -1.6 & 0.5 \\
\hline France 95-97 & 2.8 & -1.1 & 71.9 & 54.7 & 9.9 & 7.5 & 1.7 & 0.2 & -0.5 \\
\hline Germany 76-77 & 1.7 & 1.5 & 83.4 & 25.1 & 18.7 & 8.7 & 3.7 & -0.6 & 0.1 \\
\hline Germany 80-85 & 5.4 & 5.4 & 87.2 & 30.8 & 21.5 & 7.6 & 0.9 & 0.9 & -2.0 \\
\hline Germany 89 & 1.7 & -2.3 & 93.9 & 44.4 & 9.6 & 6.5 & 2.2 & 0.5 & -2.2 \\
\hline Germany 92-98 & 4.8 & -3.6 & 92.4 & 41.2 & 8.6 & 8.5 & -0.7 & -0.6 & -0.9 \\
\hline Ireland 82-84 & 6.5 & -5.8 & 44.7 & 76.4 & 15.7 & 17.3 & 2.1 & -0.2 & -1.3 \\
\hline Ireland $86-89$ & 8.7 & 6.9 & 40.9 & 103.5 & 8.5 & 12.6 & 0.7 & -1.6 & -2.2 \\
\hline Ireland 91-93 & 2.7 & 1.5 & 40.7 & 97.4 & 15.2 & 10.1 & -1.2 & -0.9 & 0.0 \\
\hline Ireland 96-98 & 2.6 & 4.5 & 44.9 & 87.9 & 25.1 & 8.3 & 2.1 & -0.8 & 0.0 \\
\hline
\end{tabular}

Notes: All variables are in percent. $t$ refers to the first year of the stabilization.

Legenda: $\operatorname{Corr}=$ cumulative change in structural budget; $m_{t+1}-m_{t-1}=$ change in the share of fixedrate long-term debt; $m_{t-1}=$ share of fixed-rate long-term debt; $B / G D P=$ debt-to-GDP ratio in the year preceding the stabilization; $\sigma_{r} / \mu_{r}=$ standard error (divided by mean) of short-term rates from auxiliary regression for the seven years preceding the stabilization; $R_{t-1}=$ long-term interest rate;

$R_{t-1}-r_{t-1}=$ spread between long- and short-term interest rates; $\Delta R_{t}=$ change of long-term interest rate; $\Delta\left(R_{t}-r_{t}\right)=$ change of spread between long- and short-term interest rates. 
Table 1 Cont'd: The Stabilization Episodes in our Sample

\begin{tabular}{|c|c|c|c|c|c|c|c|c|c|}
\hline Episode & Corr & $m_{t+1}-m_{t-1}$ & $m_{t-1}$ & $B / G D P$ & $\sigma_{r} / \mu_{r}$ & $R_{t-1}$ & $R_{t-1}-r_{t-1}$ & $\Delta R_{t}$ & $\Delta\left(R_{t}-r_{t}\right)$ \\
\hline Italy $76-77$ & 4.2 & 0.6 & 36.8 & 57.6 & 21.3 & 10.0 & -0.6 & 2.6 & -2.4 \\
\hline Italy 80 & 1.7 & -9.0 & 30.4 & 60.7 & 19.4 & 13.0 & 1.2 & 2.2 & -3.1 \\
\hline Italy $82-83$ & 3.7 & -9.2 & 21.4 & 60.3 & 14.5 & 19.4 & 0.1 & 0.9 & 0.3 \\
\hline Italy 86 & 1.2 & 3.0 & 11.0 & 82.3 & 5.4 & 13.7 & -1.5 & -2.2 & -0.4 \\
\hline Italy $88-89$ & 1.1 & 5.5 & 14.0 & 90.6 & 6.8 & 10.6 & -0.7 & 0.3 & 0.8 \\
\hline Italy 91 & 1.5 & 4.7 & 18.5 & 106.5 & 9.2 & 13.5 & 1.6 & -0.4 & -0.4 \\
\hline Italy 93 & 3.8 & 6.8 & 23.2 & 116.8 & 11.1 & 13.7 & -0.6 & -2.4 & 1.3 \\
\hline Italy $95-97$ & 5.3 & 7.4 & 30.9 & 123.9 & 13.6 & 10.5 & 2.0 & 1.7 & -0.3 \\
\hline Japan 79-87 & 7.8 & 4.6 & 82.9 & 39.7 & 13.2 & 6.4 & 1.3 & 2.0 & 1.1 \\
\hline Netherl 77 & 1.0 & -1.0 & 89.7 & 41.4 & 33.5 & 9.0 & 2.1 & -0.9 & 1.5 \\
\hline Netherl 81-83 & 2.7 & 4.9 & 92.8 & 46.9 & 31.0 & 10.2 & -0.5 & 1.3 & 0.4 \\
\hline Netherl 85 & 1.2 & -0.3 & 98.8 & 66.8 & 19.1 & 8.1 & 2.0 & -0.8 & -1.0 \\
\hline Netherl 87-88 & 1.6 & 0.1 & 98.5 & 73.5 & 13.5 & 6.3 & 0.6 & 0.1 & 0.4 \\
\hline Netherl 91 & 2.8 & 0.7 & 98.7 & 78.8 & 11.3 & 8.9 & 0.2 & -0.2 & -0.8 \\
\hline Netherl 93 & 2.0 & -2.7 & 99.5 & 79.6 & 8.2 & 8.1 & -1.3 & -1.7 & 0.8 \\
\hline Netherl 95-97 & 2.0 & -3.5 & 96.7 & 79.1 & 6.2 & 6.9 & 1.7 & 0.0 & 0.8 \\
\hline Portug 84-86 & 8.5 & -2.9 & 7.1 & 49.7 & 13.8 & 26.6 & 3.8 & 3.2 & 1.0 \\
\hline Portug 92 & 2.8 & 8.0 & 7.9 & 70.2 & 7.6 & 21.3 & 3.5 & -3.6 & 1.0 \\
\hline Portug 94-97 & 2.0 & 5.0 & 15.9 & 67.5 & 7.3 & 17.7 & 5.3 & -0.9 & 0.0 \\
\hline Spain 79 & 1.0 & 6.0 & 15.3 & 14.4 & 42.9 & 11.9 & -5.7 & 1.4 & 3.5 \\
\hline Spain 83-84 & 1.3 & -13.0 & 24.5 & 30.4 & 17.9 & 16.0 & -0.3 & 0.9 & -2.8 \\
\hline Spain $86-87$ & 2.0 & 11.6 & 13.4 & 50.8 & 10.6 & 13.4 & 1.1 & -2.0 & -1.4 \\
\hline Spain 91-94 & 3.5 & 9.0 & 30.3 & 50.3 & 10.2 & 14.6 & -0.6 & -1.8 & 0.2 \\
\hline Spain 96-97 & 4.0 & 7.9 & 54.0 & 70.8 & 5.5 & 10.9 & 1.5 & -2.2 & -0.2 \\
\hline Sweden $75-76$ & 2.7 & -1.0 & 90.7 & 30.4 & 20.7 & 8.0 & 0.7 & 1.0 & 0.5 \\
\hline Sweden $83-84$ & 2.2 & -4.4 & 59.2 & 61.7 & 12.1 & 13.3 & 0.0 & -0.7 & 1.1 \\
\hline Sweden $86-87$ & 5.6 & 3.2 & 49.8 & 66.7 & 10.4 & 13.2 & -0.9 & -2.7 & 1.6 \\
\hline Sweden 89 & 1.1 & -6.3 & 51.6 & 53.1 & 11.5 & 11.4 & 1.3 & -0.2 & -1.6 \\
\hline Sweden 94-98 & 14.3 & 8.1 & 43.9 & 75.8 & 11.9 & 8.5 & 0.2 & 1.0 & 1.9 \\
\hline UK 77 & 1.6 & 2.5 & 73.4 & 60.0 & 15.6 & 13.6 & 2.0 & -1.6 & 2.0 \\
\hline UK 79-82 & 5.8 & 3.5 & 76.0 & 57.3 & 18.0 & 12.1 & 2.8 & 0.9 & -3.6 \\
\hline UK 88-90 & 2.4 & -10.6 & 68.6 & 55.6 & 10.6 & 9.6 & -0.1 & 0.1 & -0.5 \\
\hline UK 94-98 & 7.2 & -1.4 & 61.0 & 56.9 & 10.7 & 7.5 & 1.5 & 0.7 & 0.2 \\
\hline USA 76-79 & 2.4 & 6.0 & 35.1 & 39.7 & 14.6 & 8.0 & 2.2 & -0.4 & 0.4 \\
\hline USA $87-89$ & 1.1 & -0.2 & 53.6 & 50.5 & 15.6 & 7.7 & 1.7 & 0.7 & 0.9 \\
\hline USA 93-98 & 4.5 & 0.8 & 49.9 & 60.1 & 7.9 & 7.0 & 3.6 & -1.1 & -0.7 \\
\hline
\end{tabular}

Notes: All variables are in percent. $t$ refers to the first year of the stabilization.

Legenda: $\operatorname{Corr}=$ cumulative change in structural budget; $m_{t+1}-m_{t-1}=$ change in the share of fixedrate long-term debt; $m_{t-1}=$ share of fixed-rate long-term debt; $B / G D P=$ debt-to-GDP ratio in the year preceding the stabilization; $\sigma_{r} / \mu_{r}=$ standard error (divided by mean) of short-term rates from auxiliary regression for the seven years preceding the stabilization; $R_{t-1}=$ long-term interest rate;

$R_{t-1}-r_{t-1}=$ spread between long- and short-term interest rates; $\Delta R_{t}=$ change of long-term interest rate; $\Delta\left(R_{t}-r_{t}\right)=$ change of spread between long- and short-term interest rates. 
Table 2: The Choice of Debt Maturity in Fiscal Stabilizations - Cross Sections of Stabilization Episodes-

\begin{tabular}{|c|c|c|c|c|c|c|c|}
\hline & \multicolumn{4}{|c|}{ OLS Estimation } & \multicolumn{3}{|c|}{ OLS Estimation } \\
\hline $\begin{array}{l}\text { Dep. Variable } \\
m_{t+1}-m_{t-1}\end{array}$ & \multicolumn{4}{|c|}{$\begin{array}{l}\text { Change in Fixed-Rate Long Debt } \\
\text { Denominated in Domestic Currency }\end{array}$} & \multicolumn{3}{|c|}{$\begin{array}{l}\text { Change in Fixed-Rate Long Debt } \\
\text { Including Foreign Denominated }\end{array}$} \\
\hline Sample & $\begin{array}{c}\text { Full } \\
\text { Sample }\end{array}$ & $\operatorname{Corr} \geq 2$ & $\begin{array}{l}\text { Corr } \geq 2 \\
\text { Dur } \geq 2 y\end{array}$ & $\begin{array}{l}B / G D P \\
\geq 0.5\end{array}$ & $\begin{array}{c}\text { Full } \\
\text { Sample }\end{array}$ & Corr $\geq 2$ & $\begin{array}{l}B / G D P \\
\geq 0.5\end{array}$ \\
\hline Observations & 72 & 51 & 44 & 44 & 72 & 51 & 44 \\
\hline Adjusted $R^{2}$ & 0.23 & 0.28 & 0.26 & 0.38 & 0.14 & 0.21 & 0.22 \\
\hline $\begin{array}{l}\text { Jarque-Bera } \\
\text { p-value }\end{array}$ & $\begin{array}{c}0.30 \\
(0.86)\end{array}$ & $\begin{array}{c}2.59 \\
(0.27)\end{array}$ & $\begin{array}{c}3.28 \\
(0.19)\end{array}$ & $\begin{array}{c}0.74 \\
(0.68)\end{array}$ & $\begin{array}{c}5.50 \\
(0.06)\end{array}$ & $\begin{array}{l}1.80 \\
(0.40)\end{array}$ & $\begin{array}{c}1.07 \\
(0.58)\end{array}$ \\
\hline Mean of Dep & 1.14 & 1.55 & 1.86 & 2.03 & 0.95 & 1.58 & 1.87 \\
\hline Constant & $\begin{array}{l}9.04^{* *} \\
(2.32)\end{array}$ & $\begin{array}{l}13.0^{* *} \\
(2.82)\end{array}$ & $\begin{array}{l}15.6^{* *} \\
(3.10)\end{array}$ & $\begin{array}{l}13.1^{* *} \\
(2.56)\end{array}$ & $\begin{array}{l}7.25^{*} \\
(1.81)\end{array}$ & $\begin{array}{l}9.61^{* *} \\
(2.27)\end{array}$ & $\begin{array}{c}5.47 \\
(1.04)\end{array}$ \\
\hline$m_{t-1}$ & $\begin{array}{c}-0.10^{* *} \\
(3.48)\end{array}$ & $\begin{aligned}-0.15^{* *} \\
(3.87)\end{aligned}$ & $\begin{array}{c}-0.16^{* *} \\
(3.56)\end{array}$ & $\begin{array}{c}-0.12^{* *} \\
(3.59)\end{array}$ & $\begin{array}{c}-0.07^{* *} \\
(2.68)\end{array}$ & $\begin{array}{c}-0.10^{* *} \\
(3.32)\end{array}$ & $\begin{array}{l}-0.07^{*} \\
(1.99)\end{array}$ \\
\hline$(B / G D P)_{t-1}$ & $\begin{array}{c}3.25 \\
(1.33) \\
\end{array}$ & $\begin{array}{c}0.58 \\
(0.18) \\
\end{array}$ & $\begin{array}{l}-1.63 \\
(0.46) \\
\end{array}$ & $\begin{array}{c}2.23 \\
(0.69) \\
\end{array}$ & $\begin{array}{c}2.51 \\
(1.02) \\
\end{array}$ & $\begin{array}{c}0.99 \\
(0.35) \\
\end{array}$ & $\begin{array}{c}4.96 \\
(1.43) \\
\end{array}$ \\
\hline$\left(\sigma_{r} / \mu_{r}\right)_{t-1}$ & $\begin{array}{c}0.17^{*} \\
(1.89)\end{array}$ & $\begin{array}{l}0.14^{* *} \\
(2.38)\end{array}$ & $\begin{array}{l}0.34^{* *} \\
(2.31)\end{array}$ & $\begin{array}{c}0.07 \\
(0.49)\end{array}$ & $\begin{array}{c}0.02 \\
(0.23)\end{array}$ & $\begin{array}{c}0.12 \\
(1.00)\end{array}$ & $\begin{array}{l}-0.15 \\
(0.94)\end{array}$ \\
\hline$R_{t-1}$ & $\begin{array}{c}-0.63^{* *} \\
(2.98)\end{array}$ & $\begin{array}{c}-0.70^{* *} \\
(2.98)\end{array}$ & $\begin{array}{c}-0.77^{* *} \\
(3.13)\end{array}$ & $\begin{array}{c}-0.79^{* *} \\
(3.14)\end{array}$ & $\begin{array}{l}-0.31^{*} \\
(1.63)\end{array}$ & $\begin{array}{l}-0.28 \\
(1.42)\end{array}$ & $\begin{array}{l}-0.17 \\
(0.62)\end{array}$ \\
\hline$\Delta R_{t}$ & $\begin{array}{c}-1.43^{* *} \\
(3.10)\end{array}$ & $\begin{array}{c}-1.37^{* *} \\
(2.56)\end{array}$ & $\begin{array}{c}-1.39^{* *} \\
(2.48)\end{array}$ & $\begin{array}{c}-2.38^{* *} \\
(4.41)\end{array}$ & $\begin{array}{c}-1.13^{* *} \\
(2.47)\end{array}$ & $\begin{array}{c}-1.01^{* *} \\
(2.07)\end{array}$ & $\begin{array}{c}-1.36^{* *} \\
(2.24)\end{array}$ \\
\hline
\end{tabular}

Notes: OLS estimation of equation (13). See Table 1 for variable definitions. Variables are in percent. The coefficient of $(B / G D P)_{t-1}$ is multiplied by 100 .

$t$-statistics are in parentheses. ${ }^{*}$ Significant at the $10 \%$ level. ${ }^{* *}$ Significant at the $5 \%$ level. 
Table 3: The Choice of Debt Maturity in Fiscal Stabilizations Adding the Yield Slope and Instrumental Variables Estimation

\begin{tabular}{|c|c|c|c|c|c|c|}
\hline & \multicolumn{3}{|c|}{ OLS Estimation } & \multicolumn{3}{|c|}{ IV Estimation } \\
\hline $\begin{array}{l}\text { Dep. Variable } \\
m_{t+1}-m_{t-1}\end{array}$ & \multicolumn{3}{|c|}{$\begin{array}{l}\text { Change in Fixed-Rate Long Debt } \\
\text { Denominated in Domestic Currency }\end{array}$} & \multicolumn{3}{|c|}{$\begin{array}{l}\text { Change in Fixed-Rate Long Debt } \\
\text { Denominated in Domestic Currency }\end{array}$} \\
\hline Sample & $\begin{array}{c}\text { Full } \\
\text { Sample }\end{array}$ & Corr $\geq 2$ & $\begin{array}{l}B / G D P \\
\geq 0.5\end{array}$ & $\begin{array}{c}\text { Full } \\
\text { Sample }\end{array}$ & Corr $\geq 2$ & $\begin{array}{l}B / G D P \\
\geq 0.5\end{array}$ \\
\hline Observations & 72 & 51 & 44 & 72 & 51 & 44 \\
\hline Adjusted $R^{2}$ & 0.28 & 0.29 & 0.41 & 0.17 & 0.23 & 0.28 \\
\hline $\begin{array}{l}\text { Jarque-Bera } \\
\text { p-value }\end{array}$ & $\begin{array}{c}0.67 \\
(0.71) \\
\end{array}$ & $\begin{array}{c}1.91 \\
(0.38) \\
\end{array}$ & $\begin{array}{c}0.76 \\
(0.68) \\
\end{array}$ & $\begin{array}{c}0.95 \\
(0.62) \\
\end{array}$ & $\begin{array}{l}1.23 \\
(0.54) \\
\end{array}$ & $\begin{array}{l}7.25^{* *} \\
(0.02)\end{array}$ \\
\hline Mean of Dep & 1.14 & 1.55 & 2.03 & 1.14 & 1.55 & 2.03 \\
\hline Constant & $\begin{array}{l}9.86^{* *} \\
(2.61)\end{array}$ & $\begin{array}{l}12.7^{* *} \\
(2.79)\end{array}$ & $\begin{array}{l}12.1^{* *} \\
(2.43)\end{array}$ & $\begin{array}{l}11.4^{* *} \\
(2.59)\end{array}$ & $\begin{array}{l}15.2^{* *} \\
(2.98)\end{array}$ & $\begin{array}{l}16.6^{* *} \\
(2.70)\end{array}$ \\
\hline$m_{t-1}$ & $\begin{array}{c}-0.11^{* *} \\
(3.64)\end{array}$ & $\begin{array}{c}-0.14^{* *} \\
(3.63)\end{array}$ & $\begin{array}{c}-0.12^{* *} \\
(3.73)\end{array}$ & $\begin{array}{c}-0.12^{* *} \\
(3.56)\end{array}$ & $\begin{array}{c}-0.16^{* *} \\
(3.89)\end{array}$ & $\begin{array}{c}-0.15^{* *} \\
(3.55)\end{array}$ \\
\hline$(B / G D P)_{t-1}$ & $\begin{array}{c}2.32 \\
(0.97)\end{array}$ & $\begin{array}{l}-0.16 \\
(0.05)\end{array}$ & $\begin{array}{c}2.81 \\
(0.89)\end{array}$ & $\begin{array}{l}1.43 \\
(0.50)\end{array}$ & $\begin{array}{l}-1.46 \\
(0.40)\end{array}$ & $\begin{array}{l}1.21 \\
(0.34)\end{array}$ \\
\hline$\left(\sigma_{r} / \mu_{r}\right)_{t-1}$ & $\begin{array}{l}0.16^{*} \\
(1.64)\end{array}$ & $\begin{array}{l}0.35^{* *} \\
(2.49)\end{array}$ & $\begin{array}{c}0.06 \\
(0.43)\end{array}$ & $\begin{array}{l}0.21^{* *} \\
(2.12)\end{array}$ & $\begin{array}{l}0.39^{* *} \\
(2.57)\end{array}$ & $\begin{array}{c}0.19 \\
(1.03)\end{array}$ \\
\hline$R_{t-1}$ & $\begin{array}{c}-0.65^{* *} \\
(3.13)\end{array}$ & $\begin{array}{c}-0.74^{* *} \\
(3.17)\end{array}$ & $\begin{array}{c}-0.80^{* *} \\
(3.21)\end{array}$ & $\begin{array}{c}-0.77^{* *} \\
(3.17)\end{array}$ & $\begin{array}{c}-0.83^{* *} \\
(3.14)\end{array}$ & $\begin{array}{c}-1.13^{* *} \\
(3.01)\end{array}$ \\
\hline$\Delta R_{t}$ & $\begin{array}{c}-1.21^{* *} \\
(2.68)\end{array}$ & $\begin{array}{c}-1.29^{* *} \\
(2.42)\end{array}$ & $\begin{array}{c}-2.14^{* *} \\
(3.93)\end{array}$ & $\begin{array}{c}-2.54^{* *} \\
(2.69)\end{array}$ & $\begin{array}{c}-2.35^{* *} \\
(2.45)\end{array}$ & $\begin{array}{c}-3.72^{* *} \\
(3.13)\end{array}$ \\
\hline$R_{t-1}-r_{t-1}$ & $\begin{array}{l}0.76^{* *} \\
(2.13)\end{array}$ & $\begin{array}{c}0.71 \\
(1.55)\end{array}$ & $\begin{array}{l}0.92^{* *} \\
(2.14)\end{array}$ & & & \\
\hline$\Delta\left(R_{t}-r_{t}\right)$ & $\begin{array}{l}0.92^{* *} \\
(2.04)\end{array}$ & $\begin{array}{c}0.70 \\
(1.22)\end{array}$ & $\begin{array}{c}0.26 \\
(0.51)\end{array}$ & & & \\
\hline
\end{tabular}

Notes: Columns 1-3: OLS estimation of equation (13) with added regressors $R_{t-1}-r_{t-1}$ and $\Delta\left(R_{t}-r_{t}\right)$. Columns: 4-6: IV estimation of equation (13). Instrument for $\Delta R_{t}$ : change in long-term interest rate over the six months preceding the stabilization. See Table 1 for variable definitions. Variables are in percent. The coefficient of $(B / G D P)_{t-1}$ is multiplied by 100 .

$t$-statistics are in parentheses. ${ }^{*}$ Significant at the $10 \%$ level. ${ }^{* *}$ Significant at the $5 \%$ level.

Hausman test:

Full sample: $t$-statistic $=1.119 \mathrm{P}$-value $=0.16$

Corr $\geq 2 \%: \quad t$-statistic $=1.176 \quad \mathrm{P}$-value $=0.20$

Sample $B / G D P \geq 0.5: \quad t$-statistic $=1.025 \quad \mathrm{P}$-value $=0.17$ 